\title{
鶏卵由来オリゴペプチドの血圧降下作用
}

\author{
吉井 寛*·城 憲秀**・坂村 修**・武山英黁** \\ 大庭理一郎 ${ }^{* * *} \cdot$ 井谷 徹**
}

\section{Antihypertensive Effect of Oligo-Peptide Derived from Hen's Eggs}

\author{
Hiroshi Yoshir*, Norihide TACHI**, Osamu SaKamura ${ }^{* *}$, Hidemaro TaKeYama ${ }^{* *}$, \\ Riichiro OHBA ${ }^{* * *}$ and Toru ITANI ${ }^{* *}$ \\ * Fine Chemical Laboratory Co., Ltd., 5-7-8, Shimoshinjo, \\ Higashiyodogawa-ku, Osaka 533-0021 \\ ** Department of Hygiene and Occupational Health. Nagoya City University, Medical \\ School, 1, Kawasumi, Mizuho-cho, Mizuho-ku, Nagoya 467-8601 \\ *** Department of Applied Microbial Technology, Faculty of Engineering, Kumamoto \\ Institute of Technology, 4-22-1, Ikeda, Kumamoto 860-0082
}

\begin{abstract}
By treating hen's eggs with a commercial crude enzyme preparation having both protease and lipase activities, an oligo-peptide was obtained. Its molecular weight was presumed to be $1000 \mathrm{Da}$ or less. The concentration of the oligo-peptide for inhibiting 50\% of angiotensin-I converting enzyme (ACE) activity $\left(\mathrm{IC}_{50}\right)$ was $1.22 \mathrm{mg} / \mathrm{ml}$. Some experimental studies have so far been carried out to investigate antihypertensive effect of ACE inhibitory peptides derived from several foods. In most of those studies, however, antihypertensive effect was evaluated after administrating peptides to spontaneously hypertensive rats (SHR) only once. Few studies have been carried out to examine the long-term effect of ACE inhibitory peptides on blood pressure, including the peptide derived from hen's eggs. In this study, the oligo-peptide derived from hen's eggs was orally administered to SHR for 12 weeks and examined for its antihypertensive effect. The blood pressure of the oligo-peptide dosage groups was significantly lower than that of a non-dosage (control) group. In addition, serum ACE activity of the oligo-peptide dosage groups was significantly lowered than that of the control group. These results show that the oligo-peptide derived from hen's eggs can be used as physiologically functional foods and pharmaceutics to control essential hypertension.
\end{abstract}

(Received May 18, 1998 ; Re-received Oct. 10, 1998, Accepted Nov. 4, 1998)

食品の持つ生体調節機能を解明しこれを䅣極的に生 体の健全性維持に役立てようという試みが近年盛んに行 われている゙．慗油,フィッシュンース（魚慗），マグロ， 酒, 納豆などに含有されているぺブチドの降圧作用に関 する研究もそうした試みの一環として実施されてい $ろ^{2) \sim 18)}$. ペプチドはレニンーアンジオテンシン系に作用 し, アンジオテンシン I 変換䣼 (ACE) 活性を阻害す
ることにより，血圧上昇を抑制すると考えられてお $り^{19) \sim 23)}$, 高血圧予防の観点から有用性が期待されてい る.これまでにも、フィッシュンース,イワシ，䇴油な どから抽出したACE 阻害ぺブチドを高血圧自然発症 ラット（SHR）に投与することにより，降圧効果を检討

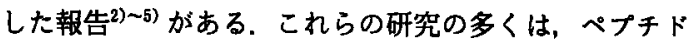
を 1 度だけ投与することにより降圧効果を検討したもの

" 株式会社ファイン化学研究所（宁533-0021 大阪市東淀川区下新庄 5-7-8）

** 名古屋市立大学医学部衛生学教室 (广467-8601 名古屋市瑞穂区瑞穂町川澄 1)

*** 熊本工業大学工学部応用微生物工学科（二860-0082 熊本市池田 4-22-1） 
であるが，食品由来のペプチドを長期間経口投与したも

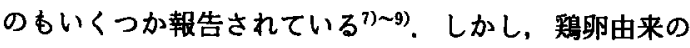
ペプチドを長期間 SHR に経口投与して，降圧効果を検 討したものは報告されていない，鷄卵から ACE 阻害ぺ プチドが得られれば，血圧降下作用を持つ食品あるいは 医薬品としての利用が期待でき，現在日本では鵎卵が生 産過剩状態にあり，低価格で大量に入手可能であるた め, 他の食品由来のぺプチドよりも利用価值が大きいと 考えられる。

\section{実 駼 目 的}

本研究では，現在日本で生産過剩状態にある䊿卵から 粗醉素を使用して ACE 阻害オリゴペプチドの調製を試 み, in vitroによる $\mathrm{ACE}$ 阻害活性および in vivoによる 降圧効果および血清 ACE 活性值抑制効果を検討した。 さらに，鶏卵由来のオリゴペプチドの長期（12 週）間投 与による降圧効果を動物実禹により検討し，本オリコぺ プチドの本態性高血圧抑制の医䍒品, 機能性食品として の有用性を実証することを目的とした。

\section{実 験 方 法}

\section{In vitro study}

(1) 醉素処理

OHBA らの方法 ${ }^{24) ~ 27) ~ に よ り ， フ ゚ ロ テ ア ー セ ゙ 及 ひ ゙ リ ~}$ パーゼ活性を併せ持っ粗醅素(Rhizopus 属起源 NewlaseF : 天野製薬(株)）を用いて，鵎卵を加水分解 (温度 : $50^{\circ} \mathrm{C}, \mathrm{pH}: 4.0$, 反応時間 : 5 時間)した. 次に, 得られた溶液の湭液（濾物は卵黄油として利用）を涷結 乾燥し，粉末化してオリゴペプチド粉末（被験物質）を 得た.

\section{(2) 分子量推定}

オリゴペプチド粉末を凍結乾燥する前の液体を限外淲 過（分子量 1000 の分子ふるい膜を用いた）することによ り，本オリコペプチドが高分子であるか低分子であるか を推定した.

(3) ACE 阻害活性測定

得られたオリコペプチド粉末の ACE 阻害活性測定を CUSHMAN らの方法 ${ }^{28292}$ を改良した MARUYAMA らの方

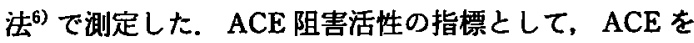
$50 \%$ 阻害するときのオリゴペプチド粉末浱度 $(\mathrm{mg} / \mathrm{m} l)$ を $\mathrm{IC}_{50}$ 値として求めた.

\section{In vivo study}

(1) 動物

雄性高血圧自然発症ラット（SHR）40 匹を 2 週間予備
飼育し，5週齢から実験を開始した。実験は， $12 \mathrm{hr}$ の 明一暗サイクル，温度 $23 \pm 0.5^{\circ} \mathrm{C}$, 湿度 $50 \sim 60 \%$ に調節さ れている名古屋市立大学医学部の動物実殹施設の Specific Pathogen Free (SPF) 域内で行い, 1 ケージあた りに 1 匹の高血圧自然発症ラット（SHR）を飼育した. 実験期間中は標準粉末眗料（オリエンタル醇母業 （株））および水は自由に摄取させた，なお，本動物実験 は名古屋市立大学実験動物ガイドラインに基づき実施し た.

(2) 投与

SHR を10 匹ずつの 4 群に分け, コントロール群 (0 $\mathrm{mg} / \mathrm{kg}$ 投与群)，20, $100,500 \mathrm{mg} / \mathrm{kg}$ オリコペプチト゚ 投与群とした。オリコペプチドは， $0.5 \mathrm{~m} l / 100 \mathrm{~g}$ B.W.の 生理的食塩水溶液に溶かし，シリンジに付けたソンデを 用いて 1 日 1 回強制的に 12 週間連続で経口投与した。 なお，コントロール群には，生理的食塩水のみを同様の 方法で投与した.

(3) 体重測定

体重測定はIshida 社製の自動はかりを用いて毎日 行った。

(4) 食触摄取量湘定

標準粉末飼料摄取量を 1 週間に 1 回, 分析用電子天秤 を用いて湘定した。

（5）歕水摄取量測定

飲水摂取量を 1 週間に 1 回，分析用電子天秤を用いて 測定した.

(6) 血圧測定

（収縮期）血圧測定は，(株)Softron 社製の非観血式自 動血圧測定装置 BP-98A を用いて, tail cuff 法により週 1 回行った.

（7）血液検查

実験終了 (実験開始 85 日目) 時，ネンプタール麻酔下 で，腹部大静脈から採血し，その血液を用いて，血清 $\mathrm{ACE}$ 活性测定を行った。 なお，血清 $\mathrm{ACE}$ 活性測定は KASAHARA らの方法 ${ }^{3031)}$ で行った.

\section{実 験 結 果}

\section{In vitro study}

オリゴペプチドは鷄卵可食部 $100 \mathrm{~g}$ あたり約 $15 \mathrm{~g}$ 得 られた.

オリゴペプチドを限外㴓過分画した結果，本オリゴペ ブチドは $90 \%$ 以上が低分子（分子量 1000 以下）であっ た.

オリゴペプチド粉末の ACE 阻害活性 $\left(\mathrm{IC}_{50}\right.$ 值) は 1.22 
$\mathrm{mg} / \mathrm{ml}$ であった.

\section{In vivo study}

各群間の食餌摄取量に有意な差は認められなかった。 しかし，投与開始 40 日目から， $500 \mathrm{mg} / \mathrm{kg}$ 投与群の体 重はその他の群に対して有意に増加した（Fig. 1). ま た，投与開始 4 週目からオリゴペプチド投与群の飲水量 が非投与群に対して有意に増加した（Fig. 2).

血圧測定の結果を Table 1 および Fig. 3 に示したが， 投与開始 3 週目からオリゴペプチド投与群において，コ ントロール群に対して有意に血圧が低下した。 また，血 液検查の結果（血清 ACE 活性）はTable 2 に示したと おりであるが, 血圧值と同様に，オリゴペプチド投与群 と非投与群の間に有意な差が認められた。

\section{考察}

高血圧症は，現在我が国の人口の約 $20 \%$ にあたる 2,000 万人以上が䍜患していると推定されている。 ヒト 高血圧の 90\% 以上は, いわゆる本態性高血圧であると いわれている ${ }^{32)}$. 本態性高血圧は，遭伝的素因をもとに， ストレスや，肥満などの種々の環境因子が作用すること によって発症する多因子疾患である ${ }^{32)}$ ，持続的な高血圧 は脳および心血管障害発症の重大な危険因子である

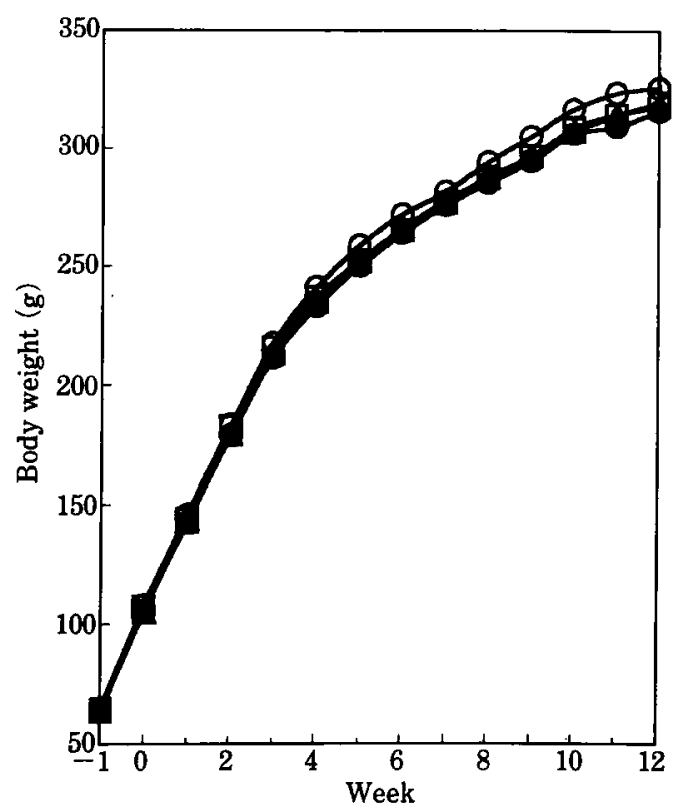

Fig. 1 Changes in body weight of SHR
. Control

O. $500 \mathrm{mg} / \mathrm{kg}$

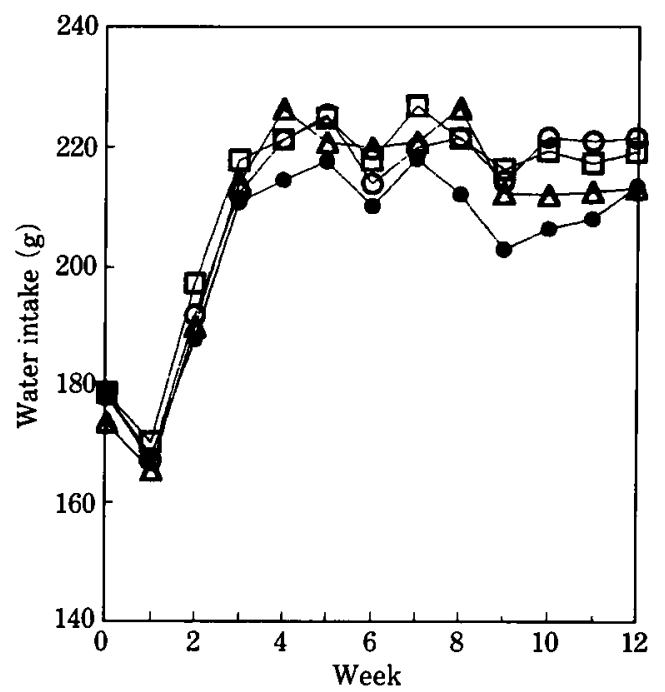

Fig. 2 Changes in water intake of SHR

- Control ; $\square, 20 \mathrm{mg} / \mathrm{kg} ; \triangle, 100 \mathrm{mg} / \mathrm{kg}$;

O. $500 \mathrm{mg} / \mathrm{kg}$

ため，血圧を適正に管理することは虚血性心疾患や頭蓋 内出血の発症を予防する上でも重要である. しかしなか ら，急激かつ過度の降圧はむしろ心筋梗塞などの心血管 事故発生率の上昇 ${ }^{34)}$, 生存率の悪化 ${ }^{35) 36)}$, 副作用発見率 の上昇 ${ }^{37)}$ な゙の様々な妍害を助長させるため，適度な降 圧効果を目的とした服薬や, 栄養, 休養, 運動などの生 活習慣の改善による高血圧コントロールが重視されてい る. 血圧の調節には複数の系の作用が関与しており, 昇 圧調節系としては, レニンーアンジオテンシン系, エンド セリン系, バソプレシン系など, 降圧調節系としては, ANP-BNP-CNP系, NO系, アドレノメジュリン系な どがある ${ }^{38) \sim 40)}$.

昇圧調節系の1つであるレニンーアンジオテンシン系 は, 水・電解質代謝, 及び偱環調節に関する最も重要な 系の1つである(1). ACE はレニンーアンジオテンシン系 の酵素であり，不活性ペプチドであるアンジオテンシン I を，強力な昇圧作用を持っアンジオテンシン II に変換 する ${ }^{42)}$. また, ACE は血管拡張作用を持つブラジキニン を不活性化する働きを持っている ${ }^{42)}$. ACE 阻害刜は,こ の ACE の働きを阻害することによって血圧上昇を抑制 するすのである

本研究の in vitroにおいて，睬卵を加水分解して得ら れたオリゴペプチドの ACE 阻害率（IC IC $_{50}$ ) は $1.22 \mathrm{mg} /$ $\mathrm{m} l$ であった. この值は, イワシ, サバ, コーンのペプチ 
Table 1 Changes in systolic blood pressure during oral administration of the oligo-peptide for 12 weeks in SHR

\begin{tabular}{|c|c|c|c|c|c|c|}
\hline \multirow{2}{*}{ Dose } & \multicolumn{6}{|c|}{ Experimental period (weeks) } \\
\hline & 0 & 1 & 2 & 3 & 4 & 5 \\
\hline Control & $136.8 \pm 8.6$ & $151.0 \pm 7.2$ & $168.8 \pm 9.3$ & $180.9 \pm 2.9$ & $192.4 \pm 8.0$ & $196.5 \pm 4.3$ \\
\hline $20 \mathrm{mg} / \mathrm{kg}$ & $140.1 \pm 11.2$ & $152.1 \pm 7.3$ & $162.7 \pm 6.9$ & $176.2 \pm 8.1$ & $184.8 \pm 10.1^{*}$ & $186.0 \pm 10.2^{* *} 1$ \\
\hline $100 \mathrm{mg} / \mathrm{kg}$ & $139.5 \pm 7.4$ & $152.3 \pm 6.4$ & $166.3 \pm 7.7$ & $172.5 \pm 6.1^{* *}$ & $179.6 \pm 11.2^{* *}$ & ${ }^{*} 182.5 \pm 8.5^{* *} 1$ \\
\hline $500 \mathrm{mg} / \mathrm{kg}$ & $141.4 \pm 13.6$ & $150.5 \pm 8.8$ & $166.9 \pm 5.5$ & $167.9 \pm 6.8^{* *}$ & $175.2 \pm 7.7^{* *}$ & $* 180.0 \pm 7.3^{* *} 1$ \\
\hline \multirow{2}{*}{ Dose } & \multicolumn{6}{|c|}{ Experimental period (weeks) } \\
\hline & 7 & 8 & 9 & 10 & 11 & 12 \\
\hline Control & $203.5 \pm 5.5$ & $205.2 \pm 6.1$ & $204.9 \pm 12.0$ & $206.8 \pm 4.7$ & $206.4 \pm 8.3$ & $208.7 \pm 5.8$ \\
\hline $20 \mathrm{mg} / \mathrm{kg}$ & $193.0 \pm 9.5^{* *}$ & $197.9 \pm 5.7^{* *}$ & $194.7 \pm 5.3^{* *}$ & $197.3 \pm 8.6^{* *}$ & $196.2 \pm 10.3^{* *}$ & ${ }^{*} 199.1 \pm 8.3^{* *}$ \\
\hline $100 \mathrm{mg} / \mathrm{kg}$ & $195.8 \pm 5.8^{* *}$ & $195.8 \pm 4.3^{* *}$ & $197.2 \pm 6.7^{*}$ & $197.5 \pm 12.4^{*}$ & $195.9 \pm 9.3^{* *}$ & ${ }^{*} 200.8 \pm 9.5^{* *}$ \\
\hline $500 \mathrm{mg} / \mathrm{kg}$ & $195.2 \pm 5.6^{* *}$ & $195.7 \pm 7.3^{* *}$ & $194.3 \pm 9.7^{*}$ & $196.3 \pm 6.9^{* *}$ & $191.9 \pm 9.0^{* *}$ & ${ }^{*} 191.7^{*} \pm 7.8^{* *}$ \\
\hline
\end{tabular}

Values are mean \pm S.D. of 10 animals. $* \mathrm{P}<0.1,{ }^{* *}: \mathrm{P}<0.05$ vs control (Student's t-test).

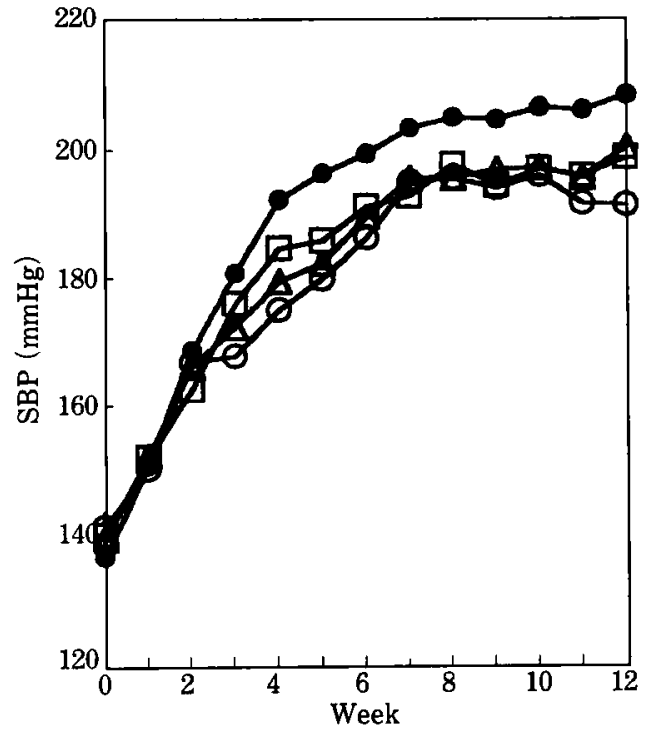

Fig. 3 Changes in SBP of SHR

O. Control ; $\square, 20 \mathrm{mg} / \mathrm{kg} ; \triangle, 100 \mathrm{mg} / \mathrm{kg}$; O, $500 \mathrm{mg} / \mathrm{kg}$

ド粗製品の值 $1.18 \sim 1.86 \mathrm{mg} / \mathrm{m} \mathrm{l}^{43)}$ と同一レベルの值で おり，鵎卵から抽出したオりゴペプチドは，食品含有物 としては中程度の ACE 阻害率を有することが明らかと なった．また，本オリゴペプチドは粗製品であるため， 分離・精製を行えぱさらに強力な ACE 阻害ペプチドの
Table 2 Serum ACE activity of SHR

\begin{tabular}{cc}
\hline \hline Dose & Serum ACE activity (IU $/ l)$ \\
\hline Control & $42.19 \pm 2.15$ \\
$20 \mathrm{mg} / \mathrm{kg}$ & $39.76 \pm 2.12^{*}$ \\
$100 \mathrm{mg} / \mathrm{kg}$ & $38.84 \pm 2.12^{*}$ \\
$500 \mathrm{mg} / \mathrm{kg}$ & $36.62 \pm 3.09^{*}$ \\
\hline
\end{tabular}

Values are mean \pm S.D. of 10 animals.

* : $\mathrm{P}<0.05$ vs control (Student's $\mathrm{t}$-test).

単離が期待できる.

in vivo 実験においては，離乳した直後から血圧が安 定するまでの 3 ヶ月間，毎日オリゴペプチドをSHRに 投与し，血圧と血清 ACE 活性を測定した．実験開始 40 日目加ら, $500 \mathrm{mg} / \mathrm{kg}$ 投与群において, 他の群に対して 有意に体重が増加していることから，オリコぺプチドを 長期間過剩摄取すると体重が増加すると考えられる．食 郋摄取量に有意な差は無いか，飲水摄取量はオリゴペプ チド投与群と非投与群との間に有意な差が見られたこと 功，オリゴペプチドを摄取すると飲水摄取量も增加す る可能性が示唆された。オリコペブチドによる降圧効果 をみると，全ての投与群において，コントロール群に対 して, 実験開始 3 週目から血圧が有意に低下している (Table 1). また， 実駼開始 3 週目から 6 週目まではオ リゴペプチドの投与量が多いほど血圧が低下する傾向が 認められた (Fig. 3). 同様に, 全ての群において, コン 
トロール群に対して，血清 $\mathrm{ACE}$ 活性が有意に減少して いる，さらに，血清 ACE 活性にはオリゴペプチドの投 与量が多くなるほど減少する傾向が認められた（Table 2).これらのこよより，オリゴペプチドの連続投与によ り，高血圧を自然発症するSHRにおける血圧上昇を抑 制することが可能であることが判明した，血圧降下は内 皮細胞の ACE の阻害と関連しているとの報告があ

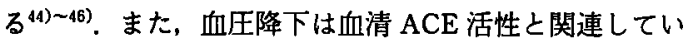
るとも報告されている47748）、今回の実験結果は，血清中 の ACE 活性値が血圧值と関連していることを示してお り、鶏卵由来のオリゴペプチドは ACE を阻害し，血圧 上昇を抑制するすのと考えられた。

以上のことより，鶏卵を加水分解して得られるオリゴ ペプチドは，生体内においても ACE 阻害活性を有し， 遭伝的な血圧上昇の抑制効果があることが明らかとなっ た。これまで鶏卵由来のぺプチドを長期間経口投与した 実験は報告されていなかったが，今回の実験結果は，彩 卵由来のペプチドの長期投与により高血圧症の発症ある いは悪化予防が可能であることを示唆している. 今後, 鷄卵由来オリゴペプチドを分離・精製し，アミノ酸配列 の解明や，副作用の検討などを通じ，本態性高血圧抑制 作用を持つ機能性食品, さらには医薬品として利用され ることが期待される.

\section{要約}

䊿卵由来オリゴペブチドの $\mathrm{ACE}$ 阻害活性 $\left(\mathrm{IC}_{50}\right)$ を測 定したところ, $1.22 \mathrm{mg} / \mathrm{ml}$ であり, 本オリコペプチドは 食品由来のペプチドとしては，ACE 阻害活性は中程度 であることが判明した。このオリゴぺプチドを分離・精 製せずに，粗製品のまま SHR に長期間経口投与するこ とにより，本オリゴペプチドの降圧効果を検討した，そ の結果, オリゴペプチド投与群の血圧はコントロール群 に対して有意に低下した。ささらに，オリコぺプチド投与 群の血清 ACE 活性がコントロール群に対して有意に低 下した．これらのことから，本オリコペプチドを粗製品 のままで長期間経口投与することにより，高血圧の発症 あるいは悪化防止が可能であることが判明した。

今後，本オリゴペプチドを分離・精製し，アミノ酸配 列を解明すれば，本オリゴペプチドの高血圧抑制の機能 性食品さらには医萝品としての利用が期待できる。

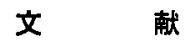

1）河村幸雄 : 食品工業, 33，20（1990）.
2）受田浩之・松田秀喜・筬島克裕・松藤 寞・松井 利郎・筬島 豊 : 農化，66，25（1992）。

3）関 英治・筬島克裕・松井利郎・筬島 豊: 日食 工誌，40, 783 (1993).

4) Окамото, А., Matsumoto, E., Iwashita, A., Yusuhara, T., KaWamura, Y., KolzUmi, Y. and Yanagida, F. : Food Sci. Technol., 1, 101 (1995).

5) Maruyama, S., Miyoshi, S., Kaneko, T. and TANAKA H. : Agric. Biol. Chem., 53, 1077 (1989).

6) Maruyama, S., Nakagomi, K., TomizuKa, N. and Suzuki, H. : Agric. Biol. Chem., 49, 1405 (1985).

7) Fujita, H., Yokoyana, K., Yatumoto, R. and YothiKawa, M. : Clinical and Experimental Pharmacology and Physiology, Suppl. 1, S 304 (1995).

8) Nakamura, Y., Masuda, O. and Takano, T. Biosci. Biotech. Biochem., 60, 488 (1996).

9) Karaki, H., DoI, K., Sugano, S., Uchiwa, H., Sugal, R., Murakami, U. and Takemoto, S. : Comp. Biochem. Physiol., 96 C, 367 (1990).

10) Kawakami, A., Kayahara, H. and Tadasa, K. Biosci. Biotech. Biochem., 59, 709 (1995).

11) Matsufuji, H., Matsui, T., Ohshige, S., KaWAsaki, T., Osauma, K. and Osajima, Y. Biosci. Biotech. Biochem., 59, 1398 (1995).

12) Matsumura, N., Fujil, M., Takeda, Y., Sugita, K. and Shizumi, T. : Biosci. Biotech. Biochem., 57, 695 (1993).

13) Kohama, Y., Matsumoto, S., OKa, H., Teramoto, T., OKaвE, M. and Mimura, T. : Biochem. Biophys. Res. Commun., 155, 332 (1988).

14) Saito, Y., Wanezaki, K., KaWato, A. and IMAYASU, S.: Biosci. Biotech. Biochem., 58, 812 (1994).

15) Saito, Y., Wanezaki, K., Kawato, A. and IMAYASU, S. : Biosci. Biotech. Biochem., 48, 1767 (1994).

16) Kinoshita, E., YamaKashi, J. and KIKUCHI, M. Biosci. Biotech. Biochem., 57, 1107 (1993).

17) OKamoto, A., Hanagata, H., Kawamura, Y. and YANAGIDA, F.: Plant Foods for Human Nutrition., 47, 39 (1995).

18) Окamoto, A., Hanagata, H., Matsumoto, E., KaWAMURA, Y. and YANAGidA, F.: Biosci. Biotech. Biochem. 59, 1147 (1995).

19) RoBert, M.H, Philip, W.S, Billy, S.A.Jr., Bassam A.A. and Mouin G.S. : Pediatric Research, 36, 671 (1994).

20) ShIono, K. and SoKabe, H. : American Journal of Physiology., 231, 1295 (1976).

21) Ashida, T., Yoshimi, H., Kawano, Y., Matsuoka, 
H. and OMAE, T. : Clinical and Experimental $H y$ pertension, 18, 851 (1996).

22) Markov, M., Higashino, H., and Suzuki, A. : Clinical and Experimental Pharmacology and Physiology, Suppl. 1, S368 (1995).

23) Markov, M., Zhelyazkov, D. and Markova, M. : Medical Archival, 27, 45 (1990).

24) Ohba, R., Teramoto, Y. and Ueda, S. : J. Food Sci., 58, 307 (1993).

25) Ohba, R., Nakashima, Y. and Ueda, S., J. Ferment. Bioeng., 78, 197 (1994).

26) Ohba, R., Nakashima, Y. and Ueda, S. : Biosci. Biotech. Biochem., 58, 2159 (1994).

27) OhBa, R., Ide, S., Yosilda, A., Nagata, $Z$. and UEDA, S. : Biosci. Biotech. Biochem., 59, 949 (1995).

28) Cushman, D. W. and Cheung, H. S. : Biochemical Pharmacology, 20, 1637 (1971).

29) Lieberman, J. : American Joumal of Medicine., 59, 356 (1975).

30）四元秀毅 : Medical Practice, 4, 217 (1987).

31) Kasahara, Y. and AshihaRA, Y.: Clinical Chemistry, 27, 1922 (1981).

32）村谷博美・柊山幸志郎：日本臨床 (高血圧), 50, 250 (1992).

33) Levy, D., Garrison, R.J., Savage, D.D., Kannel, W.B. and CASTELLI, W.P. : New England Journal of Medicine., 322, 1561 (1991).

34) Patty, B.M., Hechbert, S.R., Koepsell, T.D., Sicovick D.S., Raghunathan T.E., WEISS N.S., RosendaAl F.R., Lemaitre R.N., SMITH N.L., W AHIaL P.W. et al. : JAMA, 274, 620 (1995).

35) Furberg, C.D., Psaty, B.M. and Meyer, J.V :
Circulation, 62, 1326 (1995).

36) CRUickshank, J., ThORP, J.M. and ZaChaRIAS, F. J. : Lancet, 1, 581 (1987).

37) Pahor, M., Guralink, J.M., Furberg, C.D., CARBonin, P. and Havilik, R.J. : Lancet, 347, 1061 (1996).

38) Preston, R.A. and Epstein, M.: Seminars in Nephrology., 15, 138 (1995).

39) RobillaRd, J.E. and NaKamura, K.T. : Biology of the Neonate, 53, 201 (1988).

40) Lopez, M.J., Garbers, D.L. and Kuhn, M. : $J$. Biol. Chem., 272, 23064 (1997).

41）村上和雄: 日本臨床 (高血圧)，50，39（1992）.

42）村上和雄: 生化学, 65, 260 (1993).

43）大庭理一郎：でん粉と食品, 21，11（1996）.

44) Bennett, M.A. and Thurston, H. : Clinical Science, 90, 21 (1996).

45) Young, R.H., Ding, Y.A., LEE, Y.M. and YEN, M. $\mathrm{H}$. : American Joumal of Hypertension., 8, 928 (1995).

46) Kahonen, M., Makynen, H., Wu X., Arvola, P. and Porsti I. : British Journal of Pharmacology, 115, 859 (1995).

47) IKemoto, F., Tanaka, M., Ito, S., Song, G.B., Tominaga, M., HiRuma, M., Takada, T., Nakamura, N. and Yamamoto, K. : J. Cardiovasc. Pharmacol., 8, 69 (1986).

48) DeMey, J.R. and VanhoutTe, P.M. : Circulation Reserch., 51, 439 (1982).

(平成 10 年 5 月 18 日受付, 平成 10 年 10 月 10 日再受付, 平成 10 年 11 月 4 日受理) 